\title{
9
}

\section{From Drunken Demeanour to Doping: Shifting Parameters of Maturation among Marshall Islanders}

\author{
Laurence Marshall Carucci
}

\section{Introduction}

In this chapter, I explore the way in which Marshallese youth, encountering the effects of globalisation, have come to include the use of hard drugs (predominantly 'Ice' [crystal methamphetamine] and its lesspurified form, meth) as strategies to adapt to the vagaries of a relatively new phase in their lives-adolescence. As others have argued, adolescence itself is a Euro-American invention that carves out a life cycle space between childhood and adulthood that found no place in gathering and fishing (or hunting) societies in which life cycle rites moved youth rapidly from childhood into adulthood. ${ }^{1}$ Marshall Islanders certainly

\footnotetext{
1 An entire debate exists around the universality of adolescence, but the terms of the debate are largely facile. For example, Chen and Farruggia (2002) stated that 'most researchers ... believe that industrialization in the late 19th century brought about the emergence of adolescence as a distinct period of the life-span' yet go on to note that 'after studying ethnographic data from more than 170 pre-industrial societies'; however, Schlegel and Barry (1991) concluded that 'almost all societies have the notion of adolescence'. Like the Human Relations Area Files' cross-cultural survey, the latter view begins with sets of functions and features. Therefore, rather than asking whether a society has a linguistic category similar to 'adolescence', Schlegell and Barry presumed that any society with initiation, then marriage, also have 'adolescence' even though many such societies initiate children into manhood or womanhood, not adolescence. Based on the SchlegeI and Barry survey, Ember et al.
} 
seem to follow this same pattern-though, at the same time, colonial/ globalising encounters are hardly new. In the Marshall Islands, they have been ongoing and actively increasing for more than 150 years. ${ }^{2}$ Linguistic change, however, lags. Therefore, local categories for children (ajiri) and mature adults (rutto) are locally derived, while no comparable collective category exists for adolescence. From the mission encounter, the category 'youth' (iuut) has been appropriated and deployed to discuss this group. ${ }^{3}$ However, the entire extension of the period between childhood and adulthood is of recent derivation having been developed as an indigenous mimetic product (Carucci 2017) of the colonial/globalising era. The new life cycle category is but one element involved in the transformation of a subsistence workforce into a capitalist one, freeing up and/or incarcerating a subset of the population in a prolonged 'unemployed' status. Along with this shift, a marked subset of lifestyle activities have been created to engage the newly constructed category of social persona: 'youth'. In this chapter, I explore some of the changes that engage Marshall Islands' iuut as they transition from childhood to adulthood, particularly the activities of Enewetak/Ujelang iuut with whom I am most familiar. While many of these changes appear to engender new opportunities for youth, they also involve vastly increased levels of uncertainty and anxiety. My primary focus here is on the shifting parameters and practices within drinking circles that have occurred as the community has moved from being a highly cohesive group living on Ujelang, the most isolated atoll in the Marshall Islands, to a transnational community with residents now spread across half of the globe, from Taiwan to North Carolina, with primary residence sites on Enewetak and Majuro in the Marshall Islands as well as on the Big Island (Hawai i).

(2017) answer their own rhetorical question, 'Is adolescence a human universal?' with 'The short answer is "yes"', even though the article began with the contention that 'almost all societies recognize adolescence'. Even in that statement, 'almost all' seems highly dubious since it lacks grounding in indigenous cosmologies. I adopt the lexical/semantic view: lacking a cultural category for adolescence provides strong evidence that, for the speakers of that language, a distinct phase of life analogous to 'adolescence' does not exist. Given that perspective, the notion that adolescence is produced as complex societies become industrialised, is most likely accurate.

2 Much earlier colonial encounters began with Saveedra in 1529, with Spain then claiming eastern sections of what came to be known as 'Micronesia' until German administration of the Marshall Islands began in 1885. Spanish colonisation had little effect on the area, however, with major EuroAmerican influences coming only with the whaling era and the introduction of Christianity in the mid-nineteenth century (Hezel 2000).

3 There are indigenous terms for pubescent, yet unmarried, females and males-jiron and lekaubut not a collective, gender undifferentiated term. 


\section{From Drinking Circles to Drugs}

Drinking circles became an integral part of the movement between youth and adulthood in early colonial times as coconut toddy (jekero) and its fermented cousin (jekmai) were incorporated into Marshallese life, coming to these atolls from Kiribati, directly to the south. It is unclear why the making of toddy did not occur at an earlier date, but nineteenth-century folklorists date the incorporation of coconut toddy to the mid-nineteenth century, perhaps during the whaling era or the missionisation and copra eras that followed. As discussed elsewhere (Carucci 1987a), as drinking circles became indigenised within the Marshall Islands, and certainly on Ujelang and Enewetak Atolls, northwest outliers of the Marshalls where I first worked with them in the 1970s and 1980s, they were a core representational element of young men's transition to adulthood (compare with Oliver 1989). As liminal performative arenas (Turner 1969), drinking circles were most frequently organised in the sleeping houses of young unmarried men, or they were convened in hidden locales in the bush (representationally, the male sphere in opposition to the village space). While almost exclusively male, in the 1970s on Ujelang, a few women classified as 'exchangers' (kokan̄: those who exchanged sexual favours for cigarettes, foods and other desirable items) were occasionally incorporated into these drinking circles. Two mature women without husbands and a couple of young, unmarried women were members of the kokan contingent. Nevertheless, in conceptual contour, the drinking circles remained young men's affairs. Their liminal character was marked by all sorts of contra-normative evidences of their unacceptability and structurally antithetical character, as judged by mature community members. The core features of drinking circles that challenged the norms included a trifecta of missionary tabus: sex (outside of marriage), smoking and drinking. Following missionisation in 1926, each of these tabus became markers of what it meant to be a Kürijen 'Christian' and young Ujelang men relished breaking those tabus. Such contrarian activities were truly the core marker of being a lekau-an unwed, maturing, young male-and, with one sole exception (a young Christian convert), all young men proclaimed their membership among the lekau through 
shared drinking, smoking (Carucci 1987b) and setting up trysts with women ${ }^{4}$ (see Marshall 1978, for a comparison of drinking performances in Chuuk).

What, then, has changed since the 1970s and what has remained the same? The most marked continuity is the way in which today's young men engage in contra-normative rites of passage to mark their transition from youth to adulthood. As in the past, these performances raise the ire of mature men and women who spend a substantial amount of time chastising young men's coming-of-age activities. With some irony, mature men today, as in the past (including church members), simultaneously castigate young men for their carousing, yet, in the shadows (though often not entirely hidden from the young men or the women) they regale audiences with humorous anecdotes of their own youthful exploits of drinking, smoking and seeking out women. Despite the tabu and a host of rhetorical admonitions, a site is thus maintained that re-legitimises the liminal space for contrarian coming-of-age performances.

The changes are more notable, with each creating certain contradictions that must be confronted within the various residential locales where Enewetak/Ujelang people now reside. As noted elsewhere (Carucci 2006, 2007), the repatriation of the exiled community from Ujelang to Enewetak in 1980, following a modest but incomplete clean-up of nuclear wastes from Enewetak Atoll, involved radical shifts in everyday life. Having stripped the main islets of all vegetation and topsoil and having repatriated the community without adequate access to fuel (on which they had become dependent for fishing), few of the subsistence activities that had occupied people's time on Ujelang could be pursued. Consequently, many residents replaced gathering and fishing with bingo and cards. Lacking the options available to their carousing cousins, church members increased their focus on food exchanges, mission trips and events that more generously supported their ministers. The expansion of bingo and cards led to, or coincided with, more drinking and smoking.

4 Many such trysts were not culturally tabu, in that shared sex among cross-cousins (potential spouses) was largely acceptable. Nevertheless, by strict church doctrine, such permitted pairings were still negatively sanctioned inasmuch as only pairs that were wed within the church should engage in sex. Such was the mission-introduced rule, even though the indigenised realisation in practice could never fully inculcate the ideal. Rather, anything other than parallel cousin (sibling) relationships received little comment and no negative sanction. Not infrequently, however, drunken young men were also accused of breaking the cross-cousin proscription, of having sex with siblings or of attempting to 'damage marriages' by having sex with married women. These acts directly conflicted with higher order cultural tabus. 
Many more women on the 'New Enewetak' played bingo and/or cards than had been the case in Ujelang, which also meant that they became increasingly available to participate in drinking and smoking circles. Thus, while drinking circles and smoking continued primarily to be discussed as occupations of young, unmarried men who defined themselves as nonChristian through those actions, many young women became involved in these activities as well.

When I asked Litenka, a young female participant, about this change in 2002, she said:

Well, there is no importance to this [change]. Life on this atoll has changed forever, so you cannot go and collect pandanus fronds and make mats or make handicraft or those sorts of things, as on Ujelang. There is not a single pandanus on Enewetak ... or, at least, one with fronds suitable for weaving, so we play bingo. And then some of the young men said we should come and combine with them and play cards. So, now there are many young women who play cards. Well, some of those belonging to the church are mad, but there is no reason for this thing (their being upset), because there is nothing at all on Enewetak now. What else could you do? Just remain stationary for a while or drift off aimlessly into the open ocean from the reef.

Disillusionment with life on the New Enewetak became apparent within a few months of people's return to the atoll. Since it was impossible to live moud in Majel (a Marshallese life) on the atoll, migration rapidly increased. This included substantial expansions in the number of Enewetak/Ujelang people residing in the government centre, Majuro and, beginning in 1991, the founding of an expatriate Enewetak/Ujelang community on the Big Island of Hawai' $i$ (see Carucci 2012). After several years, drug use within these new communities began to include substances other than alcohol and tobacco. With the exception of marijuana and betel, this exploration of new recreational drugs did not affect young people on Enewetak, since open supply lines did not exist. Indeed, contact between Majuro and Enewetak has been reduced from what were monthly (at times, even weekly) airlines flights, to four planned supply ship trips per year since the beginning of the twenty-first century.

On the Big Island and on Majuro, the situation has been rather different. In a blind attempt to exploit every commercial opportunity, outside immigrants, many from Taiwan, received a government welcome to Majuro. The new immigrants brought superior entrepreneurial skills, 
resulting in the monopolisation of all sorts of trade and marketing opportunities on the atoll. Consequently, one of the largest complaints by Marshallese living in Majuro relates to their dependence on businesses that are owned and operated by Taiwanese people. Rapid in-migration also brought gang activity to Majuro and, along with those gangs, access to illegal drugs. ${ }^{5}$

As with many other activities on the Big Island, the presence of drugs long preceded the migration of Marshall Islanders. Nevertheless, between 1991 and 2010, young Marshallese men did not become involved in the local drug trade (other than some experimentation with marijuana, which was relatively easy to obtain). However, beginning with the second generation of Enewetak/Ujelang residents on the Big Island, that has changed. This new phase does not represent a gradual move towards a greater assimilation of Marshall Islanders into Big Island life, since significant effort is still dedicated towards community cohesionbuilding (separation-maintaining) Marshallese activities, such as distinct Marshallese churches and church activities, keemem (first birthday parties), celebrations of death and other group events. However, the involvement with hard drugs does reflect larger alterations in the continuity of transmitted identities between older and younger males and females. As is true in many societies, this disjunction affects men more than women. That is, the everyday activities of young men are hardly recognisable when compared to their adult male elders. The life course options available to them are entirely different than the normal maturation opportunities pursued by their fathers and grandfathers. As boys and maturing young men, members of older generations learned to fish, make canoes, climb coconut trees, gather other subsistence foods and build houses. Even though the rites of passage into adulthood inverted acceptable everyday practices for male elders, as remains true for today's youth, boys and young men on the Big Island now learn only a little about the subsistence pursuits that would occupy their time as adults — though, they would learn far more about house building than canoe construction. In brief, today's Big Island Marshallese youth will rarely mature to replicate and advance

5 Alcohol was also illegal on Ujelang, though that hardly prevented young men from imbibing. Imported alcoholic beverages, primarily cheap whisky and vodka, were only available during and immediately following the visit of the field trip ships that brought all sorts of other desirable commodities as well, but jemani and iiej (a fermented yeast concoction) supplemented bottled alcohol once a field trip ship had departed. 
the activities of their male elders. While the same is true of young women living on the Big Island or on the mainland in the US, several domestic activities do provide a minimal sense of identity continuity through time.

The lack of a practice-grounded, shared, cross-generational identity has served to increase the rift between Big Island Marshallese elders and the community's youth. Elders now frequently complain that they are powerless to alter the actions of young men and women, even close family members. This is quite unlike the situation on Ujelang in the 1970s. Certainly, even in that era, elders complained about the contrarian activities of youth, but extended family members did not hesitate to verbally sanction what they saw as antisocial engagements of young people, be they members of their own household or more distant relatives. At the collective level, the Ujelang Council (comprised of all adult household heads) frequently assigned the youth community service work-such as cleaning the main path or repairing the wharf-if young men or, occasionally, young women did not adhere to their pronouncements regarding morally acceptable activities. In diasporic communities, including Majuro, no such organised disciplinary authority exists. ${ }^{6}$ Drug use among youth has increased this sense of anomie for the youth themselves and for the adult members of the community.

As with other sources of alienation, the anomie derives from a lack of shared experience. While elder men tell stories of their drunken exploits as youth, none have any experience with drugs. Be it Ice, meth or some other legally restricted substance, the elders thereby discuss the drug effects on the youth as out of control: crazy (bwebwe), like a wild person (einwot auwie), lacking consciousness (jaji lokjen) and unfettered by custom (ejaji manit). While they attempt to control the actions of youth under the influence of drugs with the standard array of communal strategies that their elders applied during their drinking years, they are frequently disappointed that these constraints are not effective.

6 Within churches, some disciplining force remains inasmuch as disobedient youth, those who fail to abide by the required moral proscriptions, will lose membership in that church. However, at the community level, no analogous group membership ban can operate because it stands in direct opposition to the immigrant community's rigorous attempts to maintain a sense of group solidarity in the face of their own foreign identity (Carucci 2012). 


\section{Dealing with Drug-Affected Youth}

The details of one encounter may help clarify the uncertainties that members of the Big Island Marshallese community faced, once young men and women began experimenting with hard drugs.

One Sunday in June 2017, a young man, Letōōbta (a pseudonym) came into the Ocean View church just as the morning service was under way. He was an Enewetak/Ujelang community member and, while the men were unsettled when he entered - fearing that he might disrupt the service since they had heard he was under the influence of drugs - they seated him near the front between a couple of men who were Letōōbta's relatives. While the young man was unsettled for the first short segment of the service, he then became more animated, drawing increasing attention to himself and away from the minister, elders and 'deaconesses' who were leading the service. These men and women were also close relatives of the young man. He stripped off his shirt, saying he was very hot, and stood up, pacing between the front row of seats and the ambo, the pulpit and altar. The service could not continue, so two elders, including the elder who owns the land on which the church was constructed, seized the young man under his armpits and attempted to escort him from the scene. This only enraged Letōōbta and he dug in his heels to resist the men who tried to remove him from the church. At this, other Enewetak/Ujelang relatives along with additional church members intervened, telling the elders to allow the young man to remain. They led him back to a seat next to the church president - that is, the first aisle seat in the first row (the highestranked chair on the male side). Letōōbta agreed to sit in that location, but he would not put his shirt back on.

The service reconvened but, a few minutes later, Letōōbta again stood up and began pacing, mumbling, gurgling and shivering, even as he reiterated that it was very hot. His hot flashes were understood by some church members as 'an attempt to throw off the evil things that had "boarded themselves upon"' Letōōbta when he took the drugs. As the youth performance group came forward and began to line up to perform some songs that they would sing at the upcoming youth conference, Letōōbta moved his chair in front of the performers, seating himself, shirtless, as though he were a special representative of the group. Some of the elders, including a highly ranked elder who owned the land, again came forward to remove him, since Letōōbta seating himself as a leader 
or chief of the group was too representationally discordant. The youth, at least in their purest form, are called naan aorek (the critical word), since in their (sexual) purity, they represent the closest thing to God. The songs that the youth planned to perform had to convey a sense of purity. Then, perhaps, that purity could be manipulated with sexually suggestive parts of their dance to generate humour among members of the audience. This complex play of innocent and then not-so-innocent simply could not be aligned with Letōōbta's restricted performative range, as he lacked both innocence and the ability to play. Defaming the church performance, his actions required a response from the elders.

As he did previously, Letōōbta resisted their efforts to remove him with great strength and determination. Finally, when the elders placed him back in his seat, one of Letōōbta’s youngest classificatory mothers came and sat at his feet, stroking his legs and feet and pleading with him to not create further damage. This type of intervention by highly valorised female relatives of the young man was the same strategy that had been used on Ujelang several years prior, when Harry, an elder in the Ocean View church, had violently confronted the mayor, his mother's brother, when inebriated. As with Letōōbta, nearly the entire community became involved in calming and containing the young man. When Letōōbta's disruptive actions had continued for about 20 minutes, the minister (at the recommendation of some elders) finally suggested that everyone move out of the church for an interlude. A food exchange to celebrate an adult's birthday, which was planned for the time between the morning and evening services, was moved into the originally planned church hour and Letōōbta was escorted out and, treated as a honoured first guest, was provided with food and drink before being encouraged to leave the church grounds. Following the birthday celebration, church members and guests reconvened to finish the early Sunday service.

Letōōbta's actions instigated a lengthy series of storytelling performances and critiques of the event. Immediately after the church service, the men began talking about Letōōbta and the day's service. Clearly, they were upset at the 'damage' (joraan) that he had created, but they were also worried that several of Letōōbta's age mates were equally 'very damaged by drugs'. The drugs were said to be quite evil-lukuun nana or nana wot im nana (even worse than bad) - but damage to the social order was just as worrisome as the personal harm that the drugs created. After much talk, I asked how the drugs differed from the alcohol that Tobin and Joniten used to consume on Ujelang (jokingly selecting two of the many church 
elders present who, in their youth, had been dedicated drinkers). Most of the men posited that 'much more damage resulted from the drugs. With alcohol, a person would be drunk but', they said, 'the following day, all the drunkenness would be gone. Maybe your head would hurt, but there would be no further damage'. Of course, their theory was not entirely true, as one story that Joniten frequently told involving a drinking episode that he and Lamentijen had engaged in while living in Ujelang Town (Majuro) ended in alcohol poisoning and Lamentijen's death. Nevertheless, it was true that the young men usually recovered and that the drinking episodes were now more manageable by the community.

The men also noted that, unlike drugs, alcohol was usually consumed in drinking circles in which each participant sequentially drank equivalent amounts from a common cup, kava style, before passing the cup to the next consumer. In contrast, the older men contended that their 'sons/grandsons did not know the method of mixing drugs'. They indicated that 'a person really had to know what they were doing because, if you mixed them improperly, I am sorry, you might collapse and die. You would never die', they said, 'from making yeast or jemani. You might be a little sick or throw up, but die? Never'. With the drugs today, 'they (the youth) never really know. They come from other people, from the American guy in the white pickup or from others, and they (the youth) do not know the content'.

\section{Shifting Parameters in Disciplining Youth}

The communal component of drinking has also been disrupted on the disciplinary end, reflecting the changed circumstances of the community. While Ujelang people in the 1970s certainly did not believe that the Earth ended when one crossed the outer reef, they essentially believed that as soon as the field trip ship departed, the meaningful outer margin of the active community was marked by the reef's edge. Adult council members were responsible for all disciplining of inebriated youth. In sharp contrast, in Majuro and on the Big Island, policemen are not elected by the local council; they are representatives of a larger community. In these locales, not only has the Enewetak/Ujelang community come to admit that they are powerless to control the actions of their youthful members, but in the worst circumstances, they turn to the police to discipline the youth on their behalf. In both locales, community members complain when the police do not follow through in a way that they deem to be appropriate. People sometimes feel that the police are too rigorous in their 
enforcement attempts, but they more often feel that the police are too lax. After Letōōbta's disruption of the church service, the men complained that, recently, when they had called the Big Island police, officers had come and picked up a group of young Marshallese men who were using drugs, handcuffed them and forced them into the back of two police cars. However, instead of taking the youth to the police station and booking them, the young men were then driven down to the Ocean View Shopping Center and were released. 'For what reason were they arrested? Just to go on and toss them aside? There is no value to a policeman of this sort.' One group of elders speculated that the police were themselves involved with the drug trade and that was the reason why they did not follow through.

Perceptively, community elders in Majuro and on the Big Island recognise that the involvement of outside people and foreign substances-from the source of the drugs to their mode of manufacture, from those who sell drugs to the young men to disciplinary personnel who are now expected to control them-has substantially changed the power relations that once surrounded the contrarian activities of the youth. When people say ejjelok ad maron ilo raan ke in (today, we have no ability/power) in relation to the performances of youth, it is the altered social conditions encountered by Ujelang/Enewetak residents in Majuro and Ocean View (Big Island) that create those feelings of distance, of being out of control.

Often, elders primarily observe difference between today's young people and their own contrarian coming-of-age routines of 30 or 40 years ago. Fundamentally, however, the more that things change, the more they have remained the same. The liminality and inversion involved in Marshallese youth coming of age is of long standing. While we do not have any in-depth descriptions of pre-Christian era coming-of-age ceremonies, elders in the 1970s indicated that such celebrations did exist for both males and females and that they were, indeed, liminal performances. Such ceremonies were disbanded by the church, if only to re-emerge on the margins. Drinking circles were one such primary form, both a re-instantiation of liminality and resistance to the Christian attempt to tabu what was in missionary eyes tabu. Therefore, Letōōbta's disruption of a Sunday service returned the church's meta-tabu to its source, bringing the prohibited within the now sanctified space of a Sunday service. His activities were hardly new, however, since today's youth rely no less on drugs and sex to mark the passage into adulthood than did their elders. As much as the church has become a central part of Marshallese life, the American Board of Commissioners for Foreign Missions (ABCFM) 
proscriptions have never settled smoothly into Marshallese cultural designs. ${ }^{7}$ Certainly, the welcoming of young women into drinking and smoking circles has been an innovation-yet, young women remain peripheral to many of the most egregious of young people's attempts to invert the cultural norms. The expansion of the array of prohibited drugs to include Ice, meth and an over-dependence on other opioid substances has certainly altered the landscape of exchange and social control in ways that are frightening and new in the eyes of community elders.

However, youth regard this differently. For them, their elders' drinking, smoking and exchanging of sexual favours are the equivalent of their own activities. Tikal, a young man who claimed to have used various experimental drugs, observed:
Well, the elders, they say that we will really be damaged by drugs. But they do not see that at the time they were young men and women (lekau im lijiron), well, they were drinking and smoking and screwing. (laughs). They were damaging all of the rules of the church, just like today, but now that they are church people, deacons and elders, now they are upset with us and say the wrongdoings have just arisen in these times. They are our bwod 'mistakes' or 'unacceptable actions'.

In certain respects, Tikal is correct. Many of the routines that accompany the transition to adulthood have been smoothly transmitted from old to young. Not only are church prohibitions inverted, but certain favoured locales - a Marshallese youth hangout near the corner of Coral and Lotus Blossom streets in Ocean View-become the routine sites where such coming-of-age fetes occur and, in most upsetting circumstances, the reveries of the youth's identity-transforming performances slip towards a more radical attention-getting cultural activity: youth suicide (Rubinstein 1983). Such suicides are strategies deployed when young community members feel abused by their close relatives or by the Marshall Islands community at large. These youth-focused disaffections are most frequently discussed among age mates in drinking circles or, presently, in the locales where drugs are shared. In 2017, building on an established Ujelang/Enewetak history of suicide, an elaborate group

7 The ABCFM, which first brought biblical teaching to Hawai' $\mathrm{i}$ in 1819 , became the Hawaiian Mission Society before coming to the Marshall Islands in the 1850s (and to Enewetak in 1926); but the markers of heathen debauchery that they introduced have remained as church-grounded ideals until the current day. 
suicide pact was planned by young men sharing drugs on the Big Island to draw attention to their sense of disempowerment. In planning a group event, the young men hoped to transform two recent sequential suicides within the community into an age-graded social movement.

The potency of suicide lies in its ability to rapidly transform the power of those who take their own lives. As living persons and as young men moving from still-maturing youth to non-corporeal ancestors, the rank of the suicide 'victims' increases immeasurably. Such non-corporeal 'spirit' beings, what David Graeber and Marshall Sahlins (2017) term 'meta-humans', have far greater power than living humans. That power is manifest in their ability to move freely between the worlds of the living and the dead, to influence human affairs and to instigate shifts in the balance of exchange relationships between living and non-corporeal beings. The choice of method for those contemplating suicide, hanging or lukwoj buruis particularly salient in terms of Marshallese communicative intent as well. The throat (buru-) is the seat of emotions for Marshall Islanders and youthful disaffection involving highly emotion-laden feelings/thoughts are displayed iconically for the entire community when young people hang themselves. The Big Island suicide pact involved seven or eight young men who felt that their collective suicide, following on the heels of their age mates' suicides, would communicate to community elders their collective sense of disenfranchisement. The young men specifically modelled their suicide plan from the suicide of Preteley on Ujelang in 1977. Preteley had hoped that his suicide would send a message of indignation to various elders who he believed had not treated him with the respect due to him being an offspring of the chiefly family. Big Island young men viewed their proposed actions in an analogous fashion. They hoped that their strategy would communicate their sense of disempowerment to the elders. If all the young men committed suicide at the same time, they believed that the collective action would be even more transformative. Rather than just 'one additional suicide', the community would be stricken with the loss of the death of an entire set of young men. Ultimately, one of the community elders heard about the pact and, admonishing some of the young men, their group suicide was never accomplished. Consequently, neither the disaffections of the young men, the adults' critiques of young people's drug use, nor the agreed-upon idea that the young men's current style of life was largely 'useless', changed in the least. 
While Tikal and other youth regarded their shared drug use as a continuation of the practices of earlier generations, some of their analogies are problematic. Indeed, Tikal spoke of the cohesion-building components to sharing hard drugs, much as an earlier generation had observed the sharing of alcohol as creating similar bonds. What is overlooked in the suggested equivalence among today's drug choices and those in the past is the matter of internal versus external power and disciplinary control. Particularly on the Big Island, the use of Schedule 1 drugs places youth at risk of serious criminal charges. With Compact of Free Association residents under increased scrutiny under the Trump presidency, such charges may be cause for deportation (Froelich 2017). Drug charges, especially criminal charges, also follow youth for their entire life. Even though Marshallese youth claim that they share drugs much like the longstanding outer-island practice of sharing alcohol or tobacco, US law does not align with this view of sharing. Even though drug sharing undoubtedly serves as a method of creating equivalence among co-participants-as was the practice in drinking circles ${ }^{8}$ - sharing Schedule 1 drugs risks elevating legal charges from 'possession' to 'distribution', which is a substantial leap in punishment and levels of disciplinary control.

\section{Conclusion}

As with all social and cultural practices, change equates with hybrid formulations that both perpetuate core features of the past and inscribe newly formulated innovations, often using mimetic practices in formulating new components. This has certainly been true of the Enewetak/Ujelang Marshallese, the most isolated of outlier groups in the Republic of the Marshall Islands. As the entire life stage that Europeans and Americans term 'adolescence' or 'youth' has been indigenised, it has moved from a rapid rite of transition from childhood to adulthood to a more elongated and elaborated phase of Marshallese life. The mimetic term adopted to describe this stage is iunt (youth). If female rites of

8 Themes of sharing are stressed not only by Marshall Islands' youth; they surface in the works of Philippe Bourgois (2009) and of Angela Garcia (2010), whose respective research among San Francisco dopefiends, and marginalised residents of the Espanola Valley (New Mexico), point to the way in which sharing and otherness are linked, helping form bonds of solidarity and inclusion among those engaging in contra-normative performances in many distinct social settings. Rocky Sexton (2010), analysing meth users' poetry, also finds solidarity themes, noting that 'in many instances, those who produce the drug will share it with friends, family, and acquaintances within local social networks, often within group use settings'. 
passage in the Marshalls were once quite private and secluded affairs, male rites during the colonial era came to incorporate the ingestion of drugs, primarily alcohol and tobacco. In recent years, however, not only have women been included in drinking and smoking circles, but the use of hard drugs has begun to supplement alcohol and tobacco, particularly among young men. Such hard drugs are mainly restricted to Majuro, the Big Island and other Marshallese communities on the US mainland. They are rarely available on outer islands like Enewetak. While these hard drugs have not radically altered the routines of sharing among age mates, the power dynamics that have shifted among diasporic Marshall Islands communities more generally_with Enewetak/Ujelang people now forming part of larger Marshallese communities, and those communities being embedded as emergent minority groups in larger sodalities-have also been inscribed in rites of passage into adulthood. With lines of power that exceed the bounds of the emergent Marshallese communities themselves, the effects on youthful practices along the path that leads from childhood to adulthood have been significantly re-contoured in ways that are partially predictable. However, with both supply and sanction extending beyond local control, the entailed outcomes of such youthful practices are also quite unsettling.

\section{References}

Bourgois, P 2009, Righteous dopefiend, University of California Press, Berkeley.

Carucci, LM 1987a, 'Jekero: Symbolizing the transition to manhood in the Marshall Islands', Micronesica, no. 20, pp. 1-17.

Carucci, LM 1987b, 'Kijen Emaan ilo Baat: Smoking circles in Marshallese society', in L Lindstrom (ed.), Drugs in Western Pacific societies, University Press of America, Washington, DC, pp. 51-74.

Carucci, LM 2006, 'Mōnnjaar eo: The church as an embodiment and expression of community on Wōjlan and Āne-wetak, Marshall Islands', Pacific Studies, vol. 26, nos 3-4, pp. 55-78.

Carucci, LM 2007, 'Life in dis-place: Re-searching processes of imagining with Enewetak-Ujelang people', Pacific Studies, vol. 27, nos 3-4, pp. 107-133.

Carucci, LM 2012, 'You'll always be family: Formulating Marshallese identities in Kona, Hawai 'i', Pacific Studies, vol. 5, nos 1-2, pp. 203-231. 
Carucci, LM 2017, 'Mimesis and reimagining identity among Marshall Islanders', in J Mageo \& E Hermann (eds), Mimesis and Pacific transcultural encounters: In time, in trade, and in ritual reconfigurations, Berghahn Books, New York, pp. 209-229.

Chen, CS \& Farruggia, S 2002, 'Culture and adolescent development', Online Readings in Psychology and Culture, vol. 6, no. 1, doi.org/10.9707/2307-0919. 1113

Ember C, Pitek E \& Ringen, EJ 2017, Adolescence, HRAF, viewed 5 June 2018, hraf.yale.edu/ehc/summaries/adolescence

Froelich, J 2017, 'Trump Immigration Enforcement Puts COFA Migrants AtRisk for Deportation', KUAF (National Public Radio) report, 18 April 2017, viewed 12 August 2018, www.kuaf.com/term/immigration?page=2\#stream/0

Garcia, A 2010, The pastoral clinic: Addiction and dispossession along the Rio Grande, University of California Press, Berkeley.

Graeber, D \& Sahlins, M 2017, On Kings, Hau Press, distributed by University of Chicago Press, Chicago, viewed 5 June 2018, haubooks.org/wp-content/ uploads/2018/01/On-Kings.pdf

Hezel, FX 2000, The first taint of civilization, University of Hawai' $\mathrm{i}$ Press, Honolulu.

Marshall, M 1978, Weekend warriors, McGraw Hill, New York.

Oliver, D 1989, Oceania: The native cultures of Australia and the Pacific Islands, vol. 1, University of Hawai'i Press, Honolulu.

Rubinstein, D 1983, 'Epidemic suicide among Micronesian adolescents', Social Science and Medicine, vol. 17, no. 10, pp. 657-665.

Schlegel, A \& Barry, H III 1991, Adolescence: An anthropological inquiry, Free Press, New York.

Sexton, RL 2010, “"Tweaking and geeking, just having some fun”: An analysis of methamphetamine poems', The Journal of Psychoactive Drugs, vol. 42, no. 3, pp. 377-383.

Turner, V 1969, The ritual process, Routledge and Kegan Paul, London. 
This text is taken from Pacific Youth: Local and Global Futures, edited by Helen Lee, published 2019 by ANU Press, The Australian National University, Canberra, Australia.

doi.org/10.22459/PY.2019.09 